\title{
Assessment of Entrepreneurship Competencies Through the Use of FLIGBY
}

\author{
Fernando Almeida \\ almd@fe.up.pt \\ University of Porto, ISPGaya \& INESC TEC, Portugal \\ Zoltan Buzady \\ zoltan@buzady.hu \\ Corvinus Business School, Corvinus University of Budapest, Hungary
}

\begin{abstract}
Serious games are increasingly being used as innovative tool for developing entrepreneurial skills, such as strategic management, leadership, communication, negotiation or decision making. FLIGBY is a serious game that was initially developed with the objective of simulating the business management process and the application of Flow theory in a business context. However, most recently it has been suggested that serious games in general, and FLIGBY in particular, can be used in other contexts, namely in the development of entrepreneurial skills. In this sense, this study tries to verify if the competences developed and evaluated in FLIGBY on the Master Analytics Profiler (MAP) can be used to evaluate the entrepreneurial capacities of the students in the context of the course of entrepreneurship in a higher education institution. The findings indicate that the performance of these students in FLIGBY is very similar to the benchmark with only small oscillations. However, some asymmetries emerged considering the educational and professional experience, such that the students of the management course showed better business-oriented thinking and IT students revealed greater time-management skills. Finally, professional experience has proved to be relevant for making decisions about stress and for the completion of managerial tasks successfully.
\end{abstract}

\section{Keywords}

Entrepreneurship; Learning; Assessment; Serious Games; Flow; FLIGBY 


\section{Introduction}

Education is a complex phenomenon and implies a careful and contextualized evaluation. Firstly, anyone might expect with good reason that a change in education (curriculum, organization or structure) has immediate implications and results. In fact, education is a gradual and interactive process, and sometimes the results can take decades to be evidenced. Secondly, education is a model whose results are not linear, in which a political or formal change has no implication on results in the same proportion. Nonetheless, there is broad consensus about that higher education institutions should contribute to building a more prosperous, fairer, more open and accountable society (Keller, 2008; Katiliüte et al., 2014; Ramaley, 2014). Furthermore, and in addition to the fundamental and historical role of universities in teaching and research, a third mission of the university arises that aims to provide an interface between the university and society. According to Loi \& Di Guardo (2015), the third mission of universities is the dimensions of innovation and technology transfer, continuing education, and social commitment.

The introduction of entrepreneurship education has a revolutionary character, since it adds to the traditional vocational training of employees and academics, the entrepreneurial culture, more appropriate to the new formats of labor relations resulting from the restructuring of the world economy. Faced with this changed scenario, educational institutions should not refrain from focusing on preparing students for job searching and focusing on life preparation and the development of self-learning, incorporating entrepreneurship education into regular curricula and the formation of new professional. The importance of the dissemination of an entrepreneurial culture at universities, in the attempt to provide an entrepreneurial environment for future professionals, is fundamental, because according to Ghina (2014) and Baptista \& Naia (2015) the traits of entrepreneurial behavior can be achieved by the practice and lived experiences, by the assimilation of structured and developed knowledge in the classroom.

Arbaugh (2010) advocates that the process of teaching entrepreneurship needs to be highly interactive and immersive to develop entrepreneurial skills in students. In this sense, serious games emerge as a pertinent approach to developing entrepreneurial skills. However, although there are several serious games for entrepreneurship learning and reports of their adoption in a university context, it is verified that most of these serious games do not include an integrated assessment process of the developed entrepreneurial competencies. This study aims to explore the process of identifying and evaluating the students' entrepreneurial skills using FLIGBY game. In total, 29 management/leadership competencies are collected, which constitutes the Master Analytics Profiler (MAP) of each player, and it becomes pertinent to evaluate the relevance of these metrics in the development of entrepreneurship skills. Additionally, this study intends to explore how FLIGBY can be used by students to assess their entrepreneurial ability. Consequently, three research questions emerged as relevant to assess during this study:

- Are the required entrepreneurship skills aligned with the dimensions assessed in FLIGBY?

- What were the indicators in which entrepreneurship students had better and worse performance?

- Is there a relationship between students' game performance and their prior course profile or professional experience?

The manuscript is structured as follows: we initially perform a literature review on entrepreneurship competencies and on the adoption of serious games and simulations for entrepreneurship learning. Consequently, the concept of Flow theory and the FLIGBY are presented. After that, the adopted methodology is presented and the main results are discussed. Finally, the main conclusions are enumerated and some relevant points for future work are given. 


\section{Literature Review}

\section{a. Entrepreneurship Competencies}

One of the most relevant studies in the field of entrepreneurship competencies was developed by Komarkova et al. (2015) to the European Commission in which authors synthesized a number of policies and initiatives in order to promote the development of entrepreneurship competencies. This report clustered the entrepreneurship competencies in three main conceptual areas: (i) operational and contextual, those referring to knowledge and skills for the creation of a new start-up; (ii) entrepreneurial, those relating to the process of identification, evaluation and exploration of a business opportunity; and (iii) conceptual and relationship, those referring to attitudes and actionoriented skills. The report presents a long list of 292 competencies, of which 120 are related to skills, 102 to knowledge and 70 to attitudes. Another model published by the European Commission that can be used as reference for designing entrepreneurship curricula is the EntreComp, also known as Entrepreneurship Competence Framework (Bacigalupo et al., 2016). EntreComp organizes entrepreneurship competencies in a spiral composed of three spheres. The core sphere includes the ideas and opportunities (e.g., vision, creativity), the intermediate sphere includes resources (e.g., motivation and perseverance, mobilizing resources and others), and the outer layer is called into action (e.g., taking the initiative, learning through experience).

The model of grouping the entrepreneurship competencies into several layers is one of the most used, which is also adopted by Mitchelmore \& Rowley (2010) that identify attitudinal, behavioral, and managerial competencies. Other approaches that extend this base model through the inclusion of new layers have emerged in recent years. Smith \& Shankar (2015) establish a four-category model composed of four dimensions: (i) achievement; (ii) personal power; (iii) planning; and (iv) relationship building. For its part, a five-tiered model is proposed by Sugars (2014) which includes two innovative dimensions (i.e., entrepreneurial investor and true entrepreneur) over previous models. This proposal highlights the entrepreneur's role in accepting market risk and his innate ability to successively create new ventures. Finally, the Entrepreneurship Competency Model proposed in 2010 establishes a six-tiered competency pyramid (ECM, 2010): (i) personal effectiveness competencies (e.g., interpersonal skills, ambition, adaptability); (ii) academic competencies (e.g., reading, writing, science and technology); (iii) workplace competencies (e.g., creative thinking, networking, planning); (iv) industry-wide technical competencies (e.g., innovation, marketing, business operation); (v) industry-sector technical competencies (e.g., micro enterprise, small business development); and (vi) management competencies and occupationspecific requirements.

Briefly, the identified models allow us to trace a gradual evolution of entrepreneurship competences. The classical models organize the competences into three fundamental competences related to the intrinsic entrepreneurial capacity of individuals, the capacity of these individuals to establish relationships and the capacity for action. On the other hand, the 4-layer models subdivide the individual's entrepreneurial skills into his/her planning and achievement capacity. On the other hand, the 5-layered models highlight the importance of the entrepreneur in taking on leadership roles and in communicating and motivating his/her employees. Finally, the 6-layer models emphasize the importance of industry knowledge for the entrepreneur to be able to create competitive advantages.

It states clear that entrepreneurship skills span multiple dimensions. In this sense, it is expected as demonstrated by Van der Hoeff (2013) that entrepreneurial teams are more successful compared to entrepreneurs who work alone. This perspective is shared by other authors who highlight the role of teamwork and the existence of members with multidisciplinary competencies in the success of an entrepreneurship project (Brinckmann \& Hoegl, 2011; Liguori et al., 2014). In fact, the existence of multidisciplinary competencies among venture promoters emerges as one of the relevant factors in a new venture performance (Jin et al., 2017). Additionally, Yoon (2018) 
advocates that entrepreneurial orientation of venture companies is determined by entrepreneurial team characteristics, such as human and social capital, and the existence of marketing top talents.

There are some studies that aim to set a priority list of key competencies for entrepreneurship. Robles \& Zárraga-Rodriguez (2015) establish a ranking of key individual competencies that defines the ability of a person to become an entrepreneur. This study uses the Delphi method to conclude that the most important competencies are: (i) risk assumption; (ii) initiative; (iii) leadership; (iv) teamwork; (v) responsibility; (vi) autonomy; (vii) self-confidence; (viii) integrity; (ix) negotiation; and $(x)$ dynamism. On the other side, competencies related to social mobility, quality of work and change management emerges at least relevant. Zarefard \& Cho (2017) explored the main relevant managerial competencies to create an innovative start-up among university students in Iran and concluded that administrative competency, knowledge and technology competence and attaining financial capability emerge as decisive elements. A similar study was developed by Lizote et al. (2018) in which they used a sample of 61 entrepreneurship courses in Brazil to conclude that the most relevant competencies to determine the entrepreneurial ability of university students are: (i) ability to search for information; (ii) commitment; and (iii) persuasion and networking.

The development and application of entrepreneurial skills are not exclusively essential in the process of creating a new venture. According to Sánchez (2012), they also influence on small firm performance because they can play a key role in organizational capability and competitive scope. Chatterjee \& Das (2016) studied the impact of five dimension skills essential for development and entrepreneurial ability, such as leadership skills, communication skills, human relation skills, technical skills and inborn aptitude, and they concluded a positive correlation between those skills on the success of micro-entrepreneurs in an Indian region. Hashim et al. (2018) also confirm this effect and advocate that dynamic capabilities mediate the relationship between entrepreneurial competencies and small firm performance.

\section{b. Serious Games and Simulations for Entrepreneurship Learning}

It is possible identify a very diverse set of technological solutions that promote the process of learning and practice entrepreneurship competencies in the market of serious games. One of the most comprehensive studies that performed a systematic literature review on this field was elaborated by Fox et al. (2018) that identified a total of 40 serious games and analyzed comparatively the characteristics offered by these serious games. This study is also of great importance for identifying six types of learning that can be acquired in entrepreneurship game environments, respectively (Fox et al., 2018):

- Active learning - engaging learning by doing, solving problems and making decisions within the game context;

- Entrepreneurial preparedness - extent to which the game draws on and adds to the learner's existing stock of experience;

- Reflective learning - ability of the game to elicit in the player logical and reflective developmental rationales;

- Situated learning - game places learners within situational contexts and promote the interaction with other players and other nonplayable characters;

- Vicarious learning - level of involvement of other stakeholders in the learning process like peers, mentors and instructors;

- Affective learning - emotional engagement with the game, which includes elements such as feelings, motivation, attitudes and values.

In addition to serious games, simulations emerge as an alternative and a highly interactive digital approach to learning entrepreneurship. The simulations seek to represent and offer a replica of a real situation. Routledge (2016) advocates that simulations provide a flexible environment where the player can define their strategies according to the rules of the game, without the consequences 
of their mistakes and bad decisions have an impact in reality. Costin et al. (2018) argue that this approach helps students to realize the complexities of running a venture, in an environment where decisions occur simultaneously and interactively.

The integration of games in the context of classroom activities is a topic addressed by several studies. At this level, it is possible to find approaches that advocate a totally focused approach in elearning and others that promote blended learning environments (includes distance and face-toface training sessions). Allegra et al. (2013) developed a web-based game called PNPVillage that allow students to simulate the process of managing a touristic company. Protopsaltis et al. (2014) describe the implementation of a project composed of a series of mini-games for entrepreneurship learning and a Web 2.0 platform that promotes the collaborative competition among students. For its part, La Guardia et al. (2014) presents a b-learning model based on classroom activities and online learning activities. The classroom activities are used for the development of soft skills, which are essential for the development of an entrepreneurial mindset; while online learning activities allow students to explore in a simulated environment the essential business concepts associated with the process of launching a new venture. Another approach that also adopts the b-learning model was followed by Almeida (2017) that adopts the ENTRExplorer SG as a complement to the training in the classroom context. In each session, several themes of the game are taught, which are later experienced by students outside the classroom while playing the game. Lamrani et al. (2017) demonstrate the use of serious games to encourage and motivate entrepreneurship education and promote youth entrepreneurship.

Some advantages and also challenges are pointed out in relation to the use of serious games for the promotion of entrepreneurship among students. Garalis \& Strazdiene (2007) carried out a study among undergraduate management students to evaluate the skills their developed through the adoption of simulation business enterprises. The findings of this study emphasize the three most important developed competencies: (i) organizational skills; (ii) communication skills; and (iii) decision making ability. For its part, Bellotti et al. (2014) emphasize several benefits, such as building problem-solving skills, applicable to real-world situations, learning by doing, high interactivity, and the promotion of multi-tasking. In this study, several issues are also addressed, such as serious games can distract students from the learning content, game difficulty cannot be appropriate for all students, and most part of serious games has a commercial purpose and lack focus on the didactical.

Although it is relatively consensual that business-focused serious games can provide students with an authentic learning experience, which will help them in acquiring core competencies for the entrepreneurial activity as established in Bacigalupo et al. (2016) framework, its impact on the increase of entrepreneurial intent is not consensual. Fellnhofer (2015) reports that the adoption of serious games contributes to the change of entrepreneurial intention and behavior and consequently has a positive effect on the creation of new companies. Similarly, Harkema \& Popescu (2015) also reported benefits in increasing the entrepreneurial intention among adults who attended an entrepreneurship course in the Netherlands. However, in the opposite direction, the results obtained by Newbery et al. (2016) indicate that the serious games had a significant negative impact on entrepreneurial intent of undergraduate students.

\section{Flow Theory and FLIGBY}

The Flow theory was introduced in positive psychology by Prof. Mihaly Csikszentmihalyi in the decade of 60. According to Csikszentmihalyi (2014), Flow is a state in which a person is completely absorbed and flowing a pleasant activity. Consequently, when a person is totally absorbed in what he/she does, then we do not realize time passing. In this state, people can produce and achieve 
their best results, because mind and body are completely integrated and immersed in the moment (Csikszentmihalyi, 2014).

The Flow state can be achieved by a careful and fair balance between two opposite states: the state of anxiety, in which the challenge placed upon the individual is superior than a person's skill level, and the state of boredom, which arises when the abilities of the people are clearly superior to the demands by the challenges. According to Author (2017), this balancing process arises sequentially, that is, when a person needs to accomplish a more difficult task, then he/she begins to learn in a gradual way, this moving away from a state of anxiety toward that of arousal and finally into Flow. Flow states can be described in terms of the following basic preconditions and characteristics (Csikszentmihalyi, 2003, pp. 42-56):

1. Balance between challenges and skills;

2. Goals are clear;

3. Immediate and clear feedback (not need to be positive but must be constructive);

4. Intense concentration;

5. Effortless action;

6. Loss of ego;

7. Sense of control;

8. Distortion of temporal experience (unaware of time, space, noise, hunger);

9. Doing an activity because it "feels good", not in expectation of any external reward.

Several authors explored the benefits offered by Flow theory in various activities. Broadly, these benefits can be grouped into three dimensions (Sahoo \& Sahu, 2009; Alexiou et al., 2012; Zumeta et al., 2016):

- Increase the emotional, cognitive and social repertoire of the individual;

- Increase employee well-being and performance;

- Raise motivation, sense of commitment and perceptions of personal growth.

Flow theory is relevant for entrepreneurs, leaders and managers, because they all have to manage people and create an environment where employees feel comfortable and enjoy their work and grow in the process of doing it. Andony (2016) and Lan et al., (2017) advocate that managers, entrepreneurs and leaders have to take the responsibility for creating a rewarding work environment that will consequently bring benefits to employee satisfaction and company results. In this sense, Flow-based entrepreneurial style will attract and retain better individuals, contribute to increased collective and individual productivity, and contribute to the formation of individuals with a more committed organizational citizenship behavior. It is also to be noted, that in order to sustain the entrepreneurial process and to constantly develop new sets and higher level of skills needed to master the complexity of the entrepreneurial venture, the entrepreneur also needs to know and apply the concept of Flow to him or herself effectively.

The concept of Flow is highly applicable to a various type of interactive learning, particularly as a serious gaming, in which we integrate the following three dimensions: (i) some theory in the process of learning; (ii) use of technology in the simulation process; and fun elements that act as games.

FLIGBY appeared in the market as a serious game integrating three dimensions: (i) learning the Flow in business; (ii) simulation using for it a practical teaching tool; and (iii) include motivating elements as games. The objective was to provide a serious game that can be used in education and training of business, management, and entrepreneurial skills and attitudes (Marer et al., 2015).

FLIGBY adopts a 3-tier architecture. A central component is the game software that is presented in an interactive mobile format that allows the player to interact with the characters on the game. 
Other component is the databank that offers a central database repository to store all data (e.g., login, profile, decision, actions, etc.) generated during the game play. Finally, the Master Analytics Profiler (MAP) is responsible to assess the performance of the player during the game. The game produces a final report for each individual player on his/her 29 management/leadership competencies measured during the game play. Table 1 synthesizes the MAP's dimensions. These dimensions have been deducted by Csikszentmihalyi (2003) based on his research interviews with dozens of CEOs of top US corporation, which is the foundation of his Good Business book.

\begin{tabular}{|c|c|}
\hline Dimension & Description \\
\hline Active listening & $\begin{array}{l}\text { Way of responding to another person that improves mutual understanding. This } \\
\text { is a method of listening that involves understanding the content of a message as } \\
\text { well as the intent of the sender and the circumstance under which the message } \\
\text { is given. Active listening is a structured form of listening and responding that } \\
\text { focuses the attention on the speaker. The listener does not have to agree with } \\
\text { the speaker - he or she must simply state what he or she thinks the speaker } \\
\text { said. }\end{array}$ \\
\hline Analytical skill & $\begin{array}{l}\text { The readinesses to visualize, articulate, and solve complex problems, and } \\
\text { concepts, and make decisions that are sensible based on the available } \\
\text { information. Such skills include demonstration of the ability to apply logical } \\
\text { thinking to gathering and analyzing information, designing and testing solutions } \\
\text { to problems, and formulating plans. }\end{array}$ \\
\hline Assertiveness & $\begin{array}{l}\text { The readiness to express your emotions and needs without violating the rights of } \\
\text { others and without being aggressive. Assertiveness is the behavior which enables } \\
\text { you to act in your own best interests, to stand up for yourself without undue } \\
\text { anxiety, to express your honest feelings comfortable, or to exercise you own } \\
\text { rights without denying the rights of others. }\end{array}$ \\
\hline Balancing skill & $\begin{array}{l}\text { The ability to maintain the same importance between things, considering them in } \\
\text { the same way. Effective leadership is about balance. A balance between } \\
\text { challenges and skills is necessary for Flow. It is easier to become completely } \\
\text { involved in a task if we believe it is doable; if it appears to be beyond our } \\
\text { capacity we tend to respond to it by feeling anxious; if the task is too easy we } \\
\text { get bored. In either case attention shifts from what needs to be accomplished- } \\
\text { the anxious person is distracted by worries about the outcome, while the bored } \\
\text { one starts searching for other things to do. The ideal condition can be expressed } \\
\text { by the simple formula: Flow occurs when both challenges and skills are high and } \\
\text { equal to each other. }\end{array}$ \\
\hline Building engagement & $\begin{array}{l}\text { The willingness to create trust and a positive, fulfilling, work-related state of } \\
\text { mind that is characterized by dedication. Dedication refers to being strongly } \\
\text { involved in one's work and experiencing a sense of significance, enthusiasm, and } \\
\text { challenge. Building someone's (the colleagues, the community) confidence in or } \\
\text { reliance on some quality or attribute of a person or a thing, or the truth in a } \\
\text { statement. }\end{array}$ \\
\hline Business-oriented thinking & $\begin{array}{l}\text { The readiness to manage situation and solve problems in order to create added } \\
\text { value to the company and in the end, create value for the } \\
\text { shareholders/stakeholders. To be successful in business development you need } \\
\text { to manage the opportunities and threats of the corporate environment and to } \\
\text { recognize organizational weaknesses to avoid, and strengths to build upon. }\end{array}$ \\
\hline
\end{tabular}




\begin{tabular}{|c|c|}
\hline Communication skills & $\begin{array}{l}\text { Set of skills that enable a person to convey information so that it is received and } \\
\text { understood. Communication skills refer to the repertoire of interpersonal } \\
\text { behavior. }\end{array}$ \\
\hline Conflict-management & $\begin{array}{l}\text { The practice of identifying and handling conflicts in a sensible, fair, and efficient } \\
\text { manner. Conflict management is the principle that all conflicts cannot necessarily } \\
\text { be resolved, but learning how to manage them can decrease the odds of } \\
\text { nonproductive escalation. }\end{array}$ \\
\hline Delegation & $\begin{array}{l}\text { The readiness to confer function or powers on another person so he or she can } \\
\text { act on behalf of the manager. Delegation empowers a subordinate to make } \\
\text { decisions (i.e., it is a shift of decision-making authority from one organizational } \\
\text { level to a lower one). }\end{array}$ \\
\hline Diplomacy & $\begin{array}{l}\text { The willingness to take into account the varying interests and values of the other } \\
\text { parties involved in the negotiation, treating those differences with respect and } \\
\text { dealing with people in a tactful manner. }\end{array}$ \\
\hline Emotional intelligence & $\begin{array}{l}\text { The capacity and readiness to understand, express and regulate emotions in } \\
\text { oneself and in others. }\end{array}$ \\
\hline Empowerment & $\begin{array}{l}\text { The skill of sharing information, rewards, and power with employees so that they } \\
\text { can take initiative and make decisions to solve problems and improve service } \\
\text { and performance. }\end{array}$ \\
\hline Entrepreneurship & $\begin{array}{l}\text { The capacity and willingness to undertake conception, organization, and } \\
\text { management of a productive venture with all attendant risks, while seeking profit } \\
\text { as a reward. Entrepreneurial spirit is a characterized by innovation and risk- } \\
\text { taking, and an essential component to succeed in an ever changing and more } \\
\text { competitive globe marketplace. }\end{array}$ \\
\hline Execution & $\begin{array}{l}\text { The act of performing, the completion of managerial tasks (execution of a plan, a } \\
\text { task, etc.), and the readiness of doing something successfully. It involves } \\
\text { managing the business aligned with the common values. Executing strategic } \\
\text { goals is by far the greatest challenge in business today. }\end{array}$ \\
\hline Feedback & $\begin{array}{l}\text { Process of giving information regarding the performance of employees, so that } \\
\text { they can act on. Feedback must be shared in a manner that is understandable } \\
\text { and perceived by them as being provided in a highly respectful manner. As an } \\
\text { organization seeks to improve its performance, feedback helps it to make the } \\
\text { required adjustments. Feedback is immediate. It is difficult for people to stay } \\
\text { absorbed in any activity unless they get timely, "online" information about how } \\
\text { well they are doing. The sense of total involvement of the Flow experience } \\
\text { derives in a large part from knowing that what one does matters and has } \\
\text { consequences. Feedback may come from colleagues or supervisors who } \\
\text { comment on performance, but preferably it is the activity itself that will provide } \\
\text { this information. }\end{array}$ \\
\hline Future orientation & The readiness to think in long terms. This is the skills of "forward-looking". \\
\hline Information gathering & $\begin{array}{l}\text { The readiness to collect adequate information to perform the next step based on } \\
\text { this information. Managers must know what information to gather, where to find } \\
\text { it, how to collect it, and ultimately how to process the collected information. }\end{array}$ \\
\hline Intuitive thinking & $\begin{array}{l}\text { Way of thinking that does not use rational processes such as facts and data. It is } \\
\text { unfocused, nonlinear, sees many things at once, views the big picture and }\end{array}$ \\
\hline
\end{tabular}




\begin{tabular}{|c|c|}
\hline & $\begin{array}{l}\text { contains perspective. Good intuition comes from years of knowledge and } \\
\text { experience that allows you to understand how people and the world works. Its } \\
\text { strength is that it can produce a rapid result. It is acting on feelings or hunches, } \\
\text { and it can also be guided by emotions. }\end{array}$ \\
\hline Involvement & $\begin{array}{l}\text { The readiness to participate in the activities of formal or information } \\
\text { teams/groups, all the way to the execution process. }\end{array}$ \\
\hline Motivational skills & $\begin{array}{l}\text { Those skills that enable a person to become motivated and work toward } \\
\text { achieving goals. This is the readiness to understand what causes a person to } \\
\text { become motivated and stay that way. It helps with making sure people are the } \\
\text { most productive that they can be. }\end{array}$ \\
\hline Organizing & $\begin{array}{l}\text { The willingness to initiate, arrange and manage several elements into a } \\
\text { purposeful structure. This is the ability to create throughout the organization a } \\
\text { network of people who can help solve implementation problems as they occur. } \\
\text { Good implementers customize this network to include individuals who can handle } \\
\text { the special types of problems anticipated in the implementation of a particular } \\
\text { strategy. }\end{array}$ \\
\hline Prioritization & $\begin{array}{l}\text { The readiness to evaluate a group of items and ranking them in their order of } \\
\text { importance or urgency. }\end{array}$ \\
\hline $\begin{array}{l}\text { Time pressured decision- } \\
\text { making }\end{array}$ & The readiness to form, facilitate and monitor teamwork and teams. \\
\hline Personal strengths & $\begin{array}{l}\text { Recognizing and applying personal strengths is the readiness to discover and to } \\
\text { put to good use those personal strengths of others that are not immediately } \\
\text { obvious. It is the realization that those strengths can potentially induce Flow } \\
\text { states in that other person and thus benefit the organization. }\end{array}$ \\
\hline Social dynamics & $\begin{array}{l}\text { Awareness of the complexity of many situations and the social dynamics that } \\
\text { govern them. This skill can be used to advance one's own interest - for the good } \\
\text { or otherwise - and/or that of the organization. }\end{array}$ \\
\hline Stakeholder management & $\begin{array}{l}\text { The ability to manage the business process, often involving trade-off, so as to } \\
\text { have a positive impact on the organizations' stakeholders, including that of } \\
\text { society at large. }\end{array}$ \\
\hline Strategic thinking & $\begin{array}{l}\text { Helps managers to set goals, to determine priorities, to review policy issues, and } \\
\text { to perform long term planning. Clear goals are necessary to reach the Flow- } \\
\text { state. For a person to become deeply involved in any activity it is essential that } \\
\text { he or she knows precisely what tasks he or she must accomplish moment by } \\
\text { moment. Of course the ultimate goals of an activity are all important but true } \\
\text { enjoyment comes from steps one takes toward attaining a goal, not from } \\
\text { actually reaching it. }\end{array}$ \\
\hline Teamwork management & The readiness to form, facilitate and monitor teamwork and teams. \\
\hline Time management & $\begin{array}{l}\text { Ability of systematic, priority-based structuring of time allocation and distribution } \\
\text { among competing demands }\end{array}$ \\
\hline
\end{tabular}

Table 1. Dimensions considered in MAP

Source: author's own illustration

FLIGBY offers 23 scenarios, in which the user will have several stages of interaction with the characters in the game. Players are presented with two to five options, and they pick one from the list. The player makes a decision and then selects the appropriate choice, which produces consequences. At each point the game provides feedback and the player moves to next scenario. 
Each decision point involves a three-step sequence: (i) the challenge; (ii) the decisions; and (iii) the outcomes/feedback.

\section{Methodology}

The methodology is organized into four phases as depicted in Figure 1 . The study employs a focus group as an approach to the simultaneous collection of qualitative and quantitative data. Focus group approach was also adopted by Gaudelli \& Taylor (2011) and Raju \& Sankar (2014) in the context of the development and use of serious games in the field of engineering and social sciences. Additionally, Queirós et al. (2017) state that focus groups are mainly useful to investigate complex behavior and allow the researcher to interact with participants.

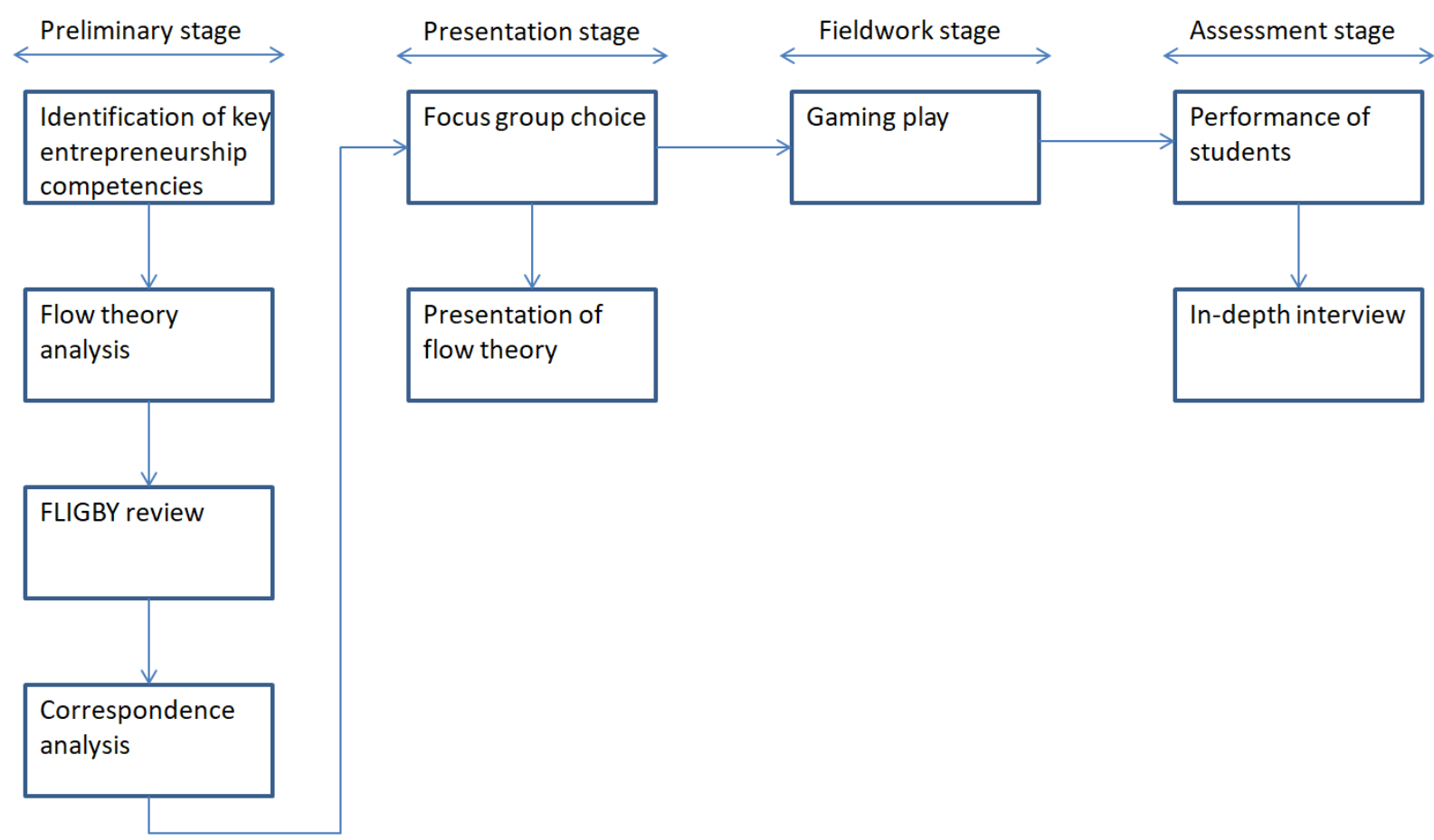

Figure. 1. Adopted methodology

Source: author's own illustration

The preliminary stage is essential to identify the key entrepreneurship competencies and understand how the flow theory and FLIGBY can foster the acquisition of fundamental skills to create a new venture. For that, a correspondence analysis was performed between the competencies evaluated in FLIGBY through the use of the MAP and the fundamental competences that an entrepreneur must possess. The result of the analysis process is mapped in Table 2. Only a maximum of 5 dimensions was considered for each competency to simplify the analysis. "N/A" means "not applied", that is, no match was found. It turns out that most entrepreneurship competencies have direct correspondence with MAP dimensions regardless of the considered model. There are only four exceptions: (i) operational and contextual, because none of the skills developed by FLIGBY is related to specific knowledge and skills needed to create a new start-up; (ii) entrepreneurial investor, because FLIGBY does not specifically assess the player's necessary financial skills, although some basic financial management skills are needed to make the best strategic decisions to ensure the viability of the business; (iii) industry-sector, because the necessary knowledge is globally transversal and not specific to a sector of activity in which a promoter can create his/her business; (iv) management and occupation-specific, since the purpose 
of the game is not to develop and apply management-specific knowledge of an activity sector, despite the relevance of the application of industry-wide knowledge. Correspondence analysis has also allowed us to identify whether all dimensions measured in FLIGBY are relevant to entrepreneurial activity, particularly those that foster the development of soft skills and the establishment of relationships between people.

\begin{tabular}{|c|c|}
\hline Entrepreneurship competencies & MAP dimensions \\
\hline \multicolumn{2}{|l|}{ 3-tiers } \\
\hline Operational and contextual & $\mathrm{N} / \mathrm{A}$ \\
\hline Entrepreneurial & $\begin{array}{l}\text { Entrepreneurship, Business-oriented thinking, Empowerment, } \\
\text { Strategic thinking }\end{array}$ \\
\hline Conceptual and relationship & $\begin{array}{l}\text { Active listening, Communication, Conflict-management, Motivation, } \\
\text { Teamwork }\end{array}$ \\
\hline \multicolumn{2}{|l|}{ 4-tiers } \\
\hline Achievement & $\begin{array}{l}\text { Engagement and trust, Business-oriented thinking, Execution, } \\
\text { Prioritizing, Timely decision-making }\end{array}$ \\
\hline Personal Power & $\begin{array}{l}\text { Analytical skills, Assertiveness, Communication, } \\
\text { intelligence, Time management }\end{array}$ \\
\hline Planning & $\begin{array}{l}\text { Balancing skill, Information gathering, Organizing, Strategic } \\
\text { thinking, }\end{array}$ \\
\hline Relationship building & $\begin{array}{l}\text { Conflict-management, Delegating, Empowerment, } \text { Feedback, } \\
\text { Involvement, Teamwork }\end{array}$ \\
\hline \multicolumn{2}{|l|}{ 5-tiers } \\
\hline Self-Employed Mindset & Organizing, Prioritizing, Time management \\
\hline Managerial Perspective & Execution, Business-oriented thinking, Teamwork \\
\hline Attitude of Owner/Leader & $\begin{array}{l}\text { Conflict-management, Delegation, Diplomacy, Motivation, Social } \\
\text { responsibility }\end{array}$ \\
\hline Entrepreneurial Investor & N/A \\
\hline True Entrepreneur & Entrepreneurship, Strategic thinking \\
\hline \multicolumn{2}{|l|}{ 6-tiers } \\
\hline Personal effectiveness & $\begin{array}{l}\text { Active listening, Communication, Emotional intelligence, Intuitive } \\
\text { thinking, Motivation }\end{array}$ \\
\hline Academic & Analytical skills \\
\hline Workplace & $\begin{array}{l}\text { Conflict-management, Delegation, Empowerment, Feedback, } \\
\text { Teamwork }\end{array}$ \\
\hline Industry-wide & $\begin{array}{l}\text { Business-oriented thinking, Entrepreneurship, Timely decision- } \\
\text { making, Social responsibility, Strategic thinking }\end{array}$ \\
\hline Industry-sector & N/A \\
\hline Management and occupation-specific & N/A \\
\hline
\end{tabular}

Table 2. Correspondence analysis between entrepreneurship competencies and MAP dimensions Source: author's own illustration

The presentation stage is a relevant phase before students play the game. Initially, a focus group has been established. According to Krueger \& Casey (2014), three elements emerge as fundamental to the definition of a focus group: (i) number of participants, which must be between 2 and maximum 12; (ii) timeframe that should be limited to two hours or less; and (iii) diversity 
that should include persons equally distributed by sex, area of expertise, academic qualifications, etc. In this sense, eight students were assigned to the focus group, of which half of them are from the management course and the other half of the computer science course; and a weekly meeting with a maximum duration of 60 minutes was defined for discussion of the learning process and problems during the game in the period of one month; and half of the students are male and female, and four of them already have a relevant professional experience (more than one year). Finally, after the definition of the members in the focus group, an informal presentation session of the Flow and FLIGBY theory was prepared. This session lasted for 90 minutes, in which $75 \%$ of this time was dedicated to the presentation of the relevant theoretical contents and $25 \%$ of the time for clarification of doubts.

The fieldwork stage is the conceptually simpler phase. From the operational point of view, it was necessary to create an individual access account for each student with their respective credentials (username and password). Additionally, the name of the regent of the entrepreneurship classes was associated as manager of this group. This allows the teacher to monitor the evolution of the players in the game, namely to know in which episode of the game each of the students is playing. Relevant statistical information is also collected as the average time of each player per episode.

The assessment stage is responsible for analyzing the students' performance in the game. Firstly, the students' performance was analyzed considering each game decision, resulting in various dimensions (such as financial results, impact on group-level atmosphere or individuals' emotional/mental states). Once the game is finished all decisions of the player are then compared to that of all other players' in the vast databank (currently over 20000) and a comparative benchmarked result of skills sets is reported. All information was automatically collected by FLIGBY and sent to the teacher in an ".xIs" format file. In FLIGBY, each player's leadership profile is comprised of his or her scores on each of the 29 leadership competencies. The profiles are automatically generated at the end of the stimulation for those who had completed the game. The continuous recording of every stroke of every player, as well as the complex statistical analysis of the results, are done routinely in the automated and pre-programmed algorithm embedded in FLIGBY's. For some of the items in the FLIGBY Leadership Skillset, a player has as many as 30 occasions to earn points; This approach means that the strength of the evidence on which a player's competence level is determined is "very well established" on certain skills and "less well established" on certain other skills in the set, but no competency item has fewer than nine decision points for its assessment. For each particular skill, the maximum number of points that can be earned is then standardized at $100 \%$. This makes it possible to determine the percentage score of each player on each skill. This approach facilitates the comparison of a player's level of skill among the 29 skills and to compare it with the average of the group the player was a member of. The approach also allows making comparative analyses, across industry sectors, by nationality background, by job tasks, among others. The designers of FLIGBY named this system as MAP, Master Analytics Profiler. It drives the individual and peer-level learning process of skills assessment and supports the trainer or teachers. More importantly, as the simulation can be repeated again and again, the individual player can use the system to improve on certain targeted skills, similarly to the functionality of a pilot's flight simulator.

Finally, an in-depth interview was conducted to allow a discussion of these results with the students, in order to understand and explain the found statistical results. This in-depth interview was held after the completion of the game by all students. Three challenging questions have been raised for debate: (i) what is the contribution of FLIGBY to the development of managerial competencies; (ii) what skills were essential during the game?; and (iii) what were the main challenges felt by the students throughout the game? 


\section{Results and Discussion}

\section{a. The students' performance}

The students' performance in the game was measured considering the 29 dimensions of the MAP (see Table 3). A unilateral hypothesis test $(a=0.05)$ was defined to evaluate whether focus group students' performance is higher than the benchmark. The results obtained allow us to conclude there are only two dimensions in which the focus group performance was lower: (i) businessoriented thinking; and (ii) prioritizing. These results indicate that students attending the entrepreneurship course show less ability to look at business from the customer's perspective and assume greater capacity to evaluate risks in the business of their decisions and performed calculated decisions. Finally, these students showed more difficulties in making decisions in stress environments, namely in identifying the priority tasks for the business. FLIGBY presents several situations in which the player has to make decisions in a short time and in which it is not possible to optimize all the processes. For example, early in the game, the player faces the challenge of scheduling meetings with employees on their first day of work, but in which the length of each meeting does not allow scheduling of sessions with all employees on that day. Setting priorities among key contributors is one of the first challenges put to the player.

\begin{tabular}{|c|c|c|c|c|c|}
\hline \multirow{2}{*}{$\begin{array}{l}\text { Performance's } \\
\text { dimensions }\end{array}$} & \multicolumn{2}{|c|}{ Focus group } & \multicolumn{2}{|c|}{ Benchmark } & \multirow[t]{2}{*}{$\operatorname{Pr}(\mu d \neq 0)$} \\
\hline & Mean & Std. dev. & Mean & Std. dev. & \\
\hline Active listening & 66 & 16 & 63 & 11,45 & $\mathrm{HO}$ \\
\hline Analytical skills & 57 & 17 & 63 & 10,76 & $\mathrm{HO}$ \\
\hline Assertiveness & 50 & 9,3 & 54 & 11,15 & $\mathrm{HO}$ \\
\hline Balancing skills & 63 & 17 & 61 & 10,5 & $\mathrm{HO}$ \\
\hline Building engagement & 67 & 6 & 65 & 8,7 & $\mathrm{HO}$ \\
\hline Business-oriented thinking & 55 & 6,1 & 61 & 9,1 & $\mathrm{H} 1$ \\
\hline Communication & 65 & 11 & 65 & 11,1 & $\mathrm{HO}$ \\
\hline Conflict management & 59 & 6,2 & 61 & 8,9 & HO \\
\hline Delegation & 58 & 14 & 60 & 14,8 & HO \\
\hline Diplomacy & 64 & 13 & 65 & 10,3 & HO \\
\hline Emotional intelligence & 69 & 11 & 70 & 9,5 & HO \\
\hline Empowerment & 65 & 17 & 58 & 14,2 & HO \\
\hline Entrepreneurship & 65 & 18 & 64 & 11,8 & HO \\
\hline Execution & 61 & 15 & 59 & 11,5 & HO \\
\hline Feedback & 68 & 15 & 67 & 11,2 & HO \\
\hline Future orientation & 67 & 10 & 67 & 10,9 & HO \\
\hline Information gathering & 71 & 11 & 71 & 10,2 & HO \\
\hline Intuitive thinking & 61 & 13 & 60 & 10,2 & HO \\
\hline Involvement & 68 & 8,1 & 70 & 11,1 & HO \\
\hline Motivation & 68 & 14 & 66 & 10,5 & HO \\
\hline Organizing & 61 & 12 & 67 & 10,8 & HO \\
\hline Prioritizing & 50 & 5,3 & 58 & 10,6 & $\mathrm{H} 1$ \\
\hline $\begin{array}{l}\text { Time pressured decision- } \\
\text { making }\end{array}$ & 49 & 19 & 57 & 10,7 & HO \\
\hline Personal strengths & 71 & 14 & 66 & 10,2 & HO \\
\hline Social dynamics & 66 & 10 & 65 & 9,2 & HO \\
\hline Stakeholder management & 64 & 21 & 63 & 14,4 & $\mathrm{HO}$ \\
\hline Strategic thinking & 59 & 14 & 62 & 10,3 & $\mathrm{HO}$ \\
\hline Teamwork management & 60 & 9,2 & 61 & 10,4 & $\mathrm{HO}$ \\
\hline Time management & 50 & 15 & 56 & 16,2 & $\mathrm{HO}$ \\
\hline
\end{tabular}

Table 3. Students' performance in FLIGBY

Source: author's own illustration 
The complementary results of the in-depth interview allowed us to conclude that unanimously all students considered that FLIGBY helped them in acquiring leadership competencies. In addition, other management areas were also referred by students, such as: customer relationship management, strategic management, decision-making process, and financial planning. It is also important to acknowledge that students expressed that the experience lived in the game was quite different, since the decisions taken by the players throughout each episode have implications in the unfolding of the game in other episodes.

\section{b. The course profile}

Table 4 outlines the performance of students considering their course profile. Statistical analysis allowed us to identify that the performance of these students was statistically significant in the following dimensions: (i) business-oriented thinking, in which IT students perform worse; (ii) empowerment, in which management students showed a better performance; (iii) prioritizing, in which the performance of the students of both courses was clearly inferior to the benchmarking; (iv) stakeholder management, in which the performance of IT students was higher; and (v) time management, in which students' performance was quite heterogeneous.

\begin{tabular}{|c|c|c|c|c|c|c|}
\hline \multirow{2}{*}{$\begin{array}{l}\text { Performance's } \\
\text { dimensions }\end{array}$} & \multicolumn{2}{|c|}{ Mng. students } & \multicolumn{2}{|c|}{ IT students } & \multicolumn{2}{|c|}{$\operatorname{Pr}(\mu d \neq 0)$} \\
\hline & Mean & Std. dev. & Mean & Std. dev. & Mng & IT \\
\hline Active listening & 60 & 11 & 74 & 21 & $\mathrm{HO}$ & $\mathrm{HO}$ \\
\hline Analytical skills & 51 & 21 & 65 & 8,1 & $\mathrm{HO}$ & HO \\
\hline Assertiveness & 47 & 11 & 54 & 5,9 & $\mathrm{HO}$ & HO \\
\hline Balancing skills & 58 & 18 & 68 & 16 & $\mathrm{HO}$ & HO \\
\hline Building engagement & 68 & 65 & 67 & 5,5 & $\mathrm{HO}$ & HO \\
\hline Business-oriented thinking & 55 & 8,4 & 54 & 2 & $\mathrm{HO}$ & $\mathrm{H} 1$ \\
\hline Communication & 61 & 13 & 70 & 2,3 & $\mathrm{HO}$ & HO \\
\hline Conflict management & 57 & 7,8 & 61 & 3,5 & $\mathrm{HO}$ & HO \\
\hline Delegation & 64 & 10 & 50 & 17 & $\mathrm{HO}$ & HO \\
\hline Diplomacy & 61 & 17 & 68 & 7,1 & $\mathrm{HO}$ & HO \\
\hline Emotional intelligence & 67 & 11 & 71 & 12 & $\mathrm{HO}$ & HO \\
\hline Empowerment & 75 & 14 & 53 & 14 & $\mathrm{H} 1$ & HO \\
\hline Entrepreneurship & 59 & 18 & 74 & 18 & $\mathrm{HO}$ & HO \\
\hline Execution & 57 & 19 & 66 & 9,5 & $\mathrm{HO}$ & HO \\
\hline Feedback & 63 & 16 & 74 & 15 & $\mathrm{HO}$ & HO \\
\hline Future orientation & 66 & 12 & 69 & 9,5 & $\mathrm{HO}$ & HO \\
\hline Information gathering & 67 & 13 & 76 & 5 & $\mathrm{HO}$ & HO \\
\hline Intuitive thinking & 57 & 12 & 66 & 14 & $\mathrm{HO}$ & HO \\
\hline Involvement & 69 & 9,5 & 67 & 7,6 & $\mathrm{HO}$ & HO \\
\hline Motivation & 66 & 16 & 71 & 13 & $\mathrm{HO}$ & HO \\
\hline Organizing & 57 & 15 & 65 & 2 & $\mathrm{HO}$ & HO \\
\hline Prioritizing & 52 & 3 & 49 & 8,2 & $\mathrm{H} 1$ & H1 \\
\hline $\begin{array}{l}\text { Time pressured decision- } \\
\text { making }\end{array}$ & 43 & 24 & 57 & 1,7 & HO & HO \\
\hline Personal strengths & 67 & 10 & 77 & 19 & HO & HO \\
\hline Social dynamics & 65 & 11 & 67 & 12 & HO & HO \\
\hline Stakeholder management & 60 & 29 & 70 & 0 & HO & H1 \\
\hline Strategic thinking & 58 & 18 & 61 & 5,5 & $\mathrm{HO}$ & HO \\
\hline Teamwork management & 62 & 12 & 59 & 4,7 & $\mathrm{HO}$ & HO \\
\hline Time management & 41 & 12 & 63 & 0 & H1 & $\mathrm{H} 1$ \\
\hline
\end{tabular}

Table 4. Students' performance in FLIGBY considering their course profile

Source: author's own illustration 
The in-depth interview allowed us to explore the causes that justify this pattern of behavior in the dimensions mentioned above. It is thus possible for us to draw the following conclusions for each dimension:

- Business-oriented thinking - students of the IT course do not have any curricular unit of management in their course. In this sense, they felt greater difficulties in perceiving the importance of identifying the needs of the client and the economic viability of the taken decisions. These results are reflected in the study developed by Moore (2004), which indicates that the nature of IT is the antithesis of the business oriented thinking;

- Prioritizing - the students expressed difficulties in defining the priority tasks for each scenario. Some students indicated they expected that each scenario would be longer and would allow them to reverse the decisions taken previously. This was a difficulty felt by all the students;

- Time management - the dynamics work of the students of these two courses is quite different. The management course is essentially organized in curricular units with a higher theoretical component in which the need for teamwork is reduced. On the other hand, IT students have curricular units with more practical assessment methods and, in many of them, they developed teamwork competencies. This situation helped them to have a better time management ability, which was reflected in the performance of these students in the game;

- Empowerment and stakeholder management - in these two dimensions it was not possible to identify the causes for the performance of students per course. A larger sample would be required to retrieve relevant information.

\section{c. The professional experience}

Table 5 presents the performance of the students considering the number of years of professional experience. Two clusters were created: (i) students without or with less than 1 year of professional experience $(P E<1)$; and (ii) students with more than one year of professional experience ( $P E \geq$ 1). The results indicate that: (i) students with $P E \geq 1$ have better execution performance, but worse prioritizing; and (ii) students with $\mathrm{PE}<1$ show less ability to perform time pressured decisions.

\begin{tabular}{|c|c|c|c|c|c|c|}
\hline \multirow[t]{2}{*}{ Performance's dimensions } & \multicolumn{2}{|c|}{ PE $<1$} & \multicolumn{2}{|c|}{ PE $\geq 1$} & \multicolumn{2}{|c|}{$\operatorname{Pr}(\mu d \neq 0)$} \\
\hline & Mean & $\begin{array}{l}\text { Std. } \\
\text { dev. }\end{array}$ & Mean & $\begin{array}{l}\text { Std. } \\
\text { dev. }\end{array}$ & $P E<1$ & $P E \geq 1$ \\
\hline Active listening & 65 & 20 & 68 & 13 & $\mathrm{HO}$ & $\mathrm{HO}$ \\
\hline Analytical skills & 50 & 19 & 67 & 9,7 & $\mathrm{HO}$ & HO \\
\hline Assertiveness & 48 & 12 & 52 & 5,7 & $\mathrm{HO}$ & $\mathrm{HO}$ \\
\hline Balancing skills & 58 & 18 & 68 & 16 & $\mathrm{HO}$ & $\mathrm{HO}$ \\
\hline Building engagement & 67 & 6,1 & 68 & 7,1 & $\mathrm{HO}$ & $\mathrm{HO}$ \\
\hline Business-oriented thinking & 53 & 6,2 & 57 & 6,4 & $\mathrm{H} 1$ & HO \\
\hline Communication & 59 & 9,9 & 72 & 6,1 & $\mathrm{HO}$ & $\mathrm{HO}$ \\
\hline Conflict management & 56 & 6,2 & 62 & 5 & $\mathrm{HO}$ & $\mathrm{HO}$ \\
\hline Delegation & 64 & 10 & 50 & 17 & HO & HO \\
\hline Diplomacy & 64 & 18 & 65 & 2,5 & $\mathrm{HO}$ & $\mathrm{HO}$ \\
\hline Emotional intelligence & 68 & 13 & 70 & 9,5 & $\mathrm{HO}$ & $\mathrm{HO}$ \\
\hline Empowerment & 66 & 9,3 & 65 & 27 & $\mathrm{HO}$ & HO \\
\hline Entrepreneurship & 61 & 21 & 71 & 16 & $\mathrm{HO}$ & $\mathrm{HO}$ \\
\hline Execution & 56 & 18 & 68 & 8,7 & $\mathrm{HO}$ & $\mathrm{H} 1$ \\
\hline Feedback & 65 & 19 & 72 & 12 & $\mathrm{HO}$ & $\mathrm{HO}$ \\
\hline Future orientation & 66 & 12 & 69 & 9,5 & HO & HO \\
\hline Information gathering & 67 & 13 & 76 & 5 & $\mathrm{HO}$ & $\mathrm{HO}$ \\
\hline Intuitive thinking & 58 & 14 & 64 & 13 & $\mathrm{HO}$ & $\mathrm{HO}$ \\
\hline
\end{tabular}




\begin{tabular}{|c|c|c|c|c|c|c|}
\hline Involvement & 65 & 9,1 & 72 & 5,8 & $\mathrm{HO}$ & $\mathrm{HO}$ \\
\hline Motivation & 65 & 14 & 72 & 15 & $\mathrm{HO}$ & $\mathrm{HO}$ \\
\hline Organizing & 57 & 15 & 65 & 2 & $\mathrm{HO}$ & $\mathrm{HO}$ \\
\hline Prioritizing & 53 & 4,5 & 47 & 5,5 & $\mathrm{HO}$ & $\mathrm{H} 1$ \\
\hline $\begin{array}{l}\text { Time pressured decision- } \\
\text { making }\end{array}$ & 39 & 17 & 63 & 12 & $\mathrm{H} 1$ & $\mathrm{HO}$ \\
\hline Personal strengths & 69 & 15 & 73 & 16 & $\mathrm{HO}$ & $\mathrm{HO}$ \\
\hline Social dynamics & 67 & 12 & 65 & 9,2 & $\mathrm{HO}$ & $\mathrm{HO}$ \\
\hline Stakeholder management & 55 & 24 & 77 & 12 & $\mathrm{HO}$ & $\mathrm{HO}$ \\
\hline Strategic thinking & 55 & 16 & 64 & 10 & $\mathrm{HO}$ & $\mathrm{HO}$ \\
\hline Teamwork management & 58 & 11 & 64 & 7 & $\mathrm{HO}$ & $\mathrm{HO}$ \\
\hline Time management & 50 & 10 & 50 & 22 & $\mathrm{HO}$ & $\mathrm{HO}$ \\
\hline
\end{tabular}

Table 5. Students' performance in FLIGBY considering their professional experience

Source: author's own illustration

Based on the in-depth interview it was possible to discuss these results and find some relevant information:

- Students with more professional experience considered that the FLIGBY learning and development experience was relevant to them so as to make more precise and correct decisions, because many of the situations exposed in the game scenarios are fully reflecting those real situations which they had already experienced in their own companies too. Their past experiences allowed these students to be better prepared for the challenges posed by FLIGBY. However, it was not possible to identify the reasons for the poor performance of these students in the skills dimension 'prioritization of activities';

- Students without relevant professional experience $(P E<1$ ) indicated that the game experience was very important in understanding and experiencing the challenges of running a business. For these students it was a surprise that many of the main challenges are in managing people and processes. They also mentioned difficulties in realizing that decisions taken in one area of the company have an impact on other areas. They also found it difficult to make the best decisions when dealing simultaneously with several people that request an immediately action. In fact, making important decisions is not easy, especially when both alternatives have positive and negative impacts. However, if we are stressed, it is more difficult to assess the situation and make a consistent choice (Driskell \& Salas, 2016). Additionally, the study conducted by De Paola \& Gioia (2014) suggest greater difficulties of undergraduate students when exposed to time pressure decisions with significant impact on students' performance both verbal and at numerical tasks. This situation was also confirmed in the FLIGBY game for students without relevant professional experience.

\section{Conclusions}

The authors have shown that FLIGBY is an innovative serious game that can be exploited for the development of entrepreneurship skills among students of a higher education institution. FLIGBY evaluates the player's performance and measures 29 management and leadership skills, which then constitute the MAP reporting system's core dimensions. The developed research study allowed us now to demonstrate that in general the basic competencies, which an entrepreneur must possess are well mapped in FLIGBY's MAP model, with the exception of some knowledge fields related to financial, industry-sector specific and occupation-specific categories. When compared with other serious games identified in the literature that promote the development of entrepreneurship competencies, the authors have found that FLIGBY offers high interactivity and engagement without compromising the pedagogical dimension. A particular benefit of FLIGBY is 
that players' performance is measured in a non-intrusive way, thus not distorted, and skills are measured on real management challenges which arise in the simulated process of managing a new venture.

The performance of the students who took part in the focus group was similar to the existing benchmark, with the exception of the business-oriented thinking and prioritizing dimensions. For these dimensions the focus group reported greater difficulties. The present study also evaluated the performance of these students considering the isolated dimensions related to their courses and years of professional experience, and some asymmetries emerged in such a way that: students of management course had better scores of business-oriented thinking, while IT students revealed greater time-management skills; students without relevant professional experience had lower business-oriented thinking and greater difficulty in making decisions about stress environments, while the students with relevant professional experience showed a greater capacity to execute management processes, but a lower ability to prioritize activities.

The results of this study have relevant practical implications since it allowed demonstrating the viability of adopting FLIGBY as a complement to the traditional models of teaching entrepreneurship that are based on theoretical expositions and applied projects. The adoption of a focus group made it possible to perceive the difficulties experienced by the students and to define a model that allows the integration of FLIGBY within the existing evaluation rules that are adopted by the educational institution. In this sense, the researchers of this project are developing efforts to involve all the students of this new school year (2018/19) to use the game FLIGBY in the context of the academic activities of the course of entrepreneurship. This future research will work with a sample of significant size (more than 50 students), which will allow us to obtain more robust and rigorous statistical results.

\section{References}

Alexiou, A., Schippers, M., \& Oshri, I. (2012). Positive Psychology and Digital Games: The Role of Emotions and Psychological Flow in Serious Games Development. Psychology, 3(12), pp. 1243-1247.

Allegra, M., La Guardia, D., Ottaviano, S., Dal Grande, V., \& Gentile, M. A serious game to promote and facilitate entrepreneurship education for Young students. In Proceedings of the 2013 International Conference on Education and Educational Technologies, Barcelona, Spain, 256-263.

Almeida, F. (2017). Experience with entrepreneurship learning using serious games. Cypriot Journal of Educational Sciences, 12(2), 69-80.

Andony, T., Gorjian, N., \& Finkelman, J. (2016). Effects of Positive Leadership and Flow on Employee WellBeing through the PERMA Lens. Austin Journal of Psychiatry and Behavioral Sciences, 3(1), pp. 10511062.

Arbaugh, J. (2010). Online and Blended Business Education for the 21st Century: Current Research and Future Directions. Oxford, UK: Chandos Publishing.

Bacigalupo, M., Kampylis, P., Punie, Y., \& Brande, G. (2016). EntreComp: The Entrepreneurship Competence Framework. JRC Science for Policy Report. Retrieved from http://publications.jrc.ec.europa.eu/repository/bitstream/JRC101581/Ifna27939enn.pdf

Baptista, R., \& Naia, A. (2015). Entrepreneurship Education: A Selective Examination of the Literature. Foundations and Trends in Entrepreneurship, 11(5), pp. 337-426.

Bellotti, F., Berta, R., De Gloria, A., Lavagnino, E., Antonaci, A., Dagnino, F., Ott, M., Romero, M., Usart, M., \& Mayer, I. (2014). Serious games and the development of an entrepreneurial mindset in higher education engineering students. Entertainment Computing, 5(4), pp. 357-366.

Brinckmann, J., \& Hoegl, M. (2011). Effects of initial teamwork capability and initial relational capability on the development of new technology-based firms. Strategic Entrepreneurship Journal, 5(1), pp. 37-57. 
Chatterjee, N., \& Das, N. (2016). A Study on the Impact of Key Entrepreneurial Skills on Business Success of Indian Micro-entrepreneurs: A Case of Jharkhand Region. Global Business Review, 17(1), pp. 226-237.

Costin, Y., O’Brien, M., \& Slattery, D. (2018). Using Simulation to Develop Entrepreneurial Skills and Mind-Set: An Exploratory Case Study. International Journal of Teaching and Learning in Higher Education, 30(1), pp. $136-145$.

Csikszentmihalyi, M. (2003). Good Business: Leadership, Flow and the Making of Meaning. New York, NY: Penguim Books.

Csikszentmihalyi, M. (2014). Flow and the Foundations of Positive Psychology. Heidelberg: Springer.

De Paola, M., \& Gioia, F. (2014). Who performs better under time pressure? Results from a field experiment. IZA Research Series. Retrieved from http://ftp.iza.org/dp8708.pdf

Driskell, J., \& Salas, E. (2016). Stress and Human Performance. Abingdon, Oxford: Psychology Press.

ECM (2010). The consortium for the entrepreneurship education. Retrieved from http://www.careeronestop.org/competencymodel/competency-models/entrepreneurship.aspx

Fellnhofer, K. (2015). Changing entrepreneurial intention and behaviour: a digital game-based learning environment dedicated to entrepreneurship education. Journal for International Business and Entrepreneurship Development, 8(4), pp. 378-404.

Fox, J., Pittaway, L., \& Uzuegbunam, I. (2018). Simulations in Entrepreneurship Education: Serious Games and Learning Through Play. Entrepreneurship Education and Pedagogy, 1(1), pp. 61-89.

Garalis, A., \& Strazdiene, G. (2007). Entrepreneurial skills development via simulation business enterprise. Social Research, 2(10), pp. 39-48.

Gaudelli, W., \& Taylor, A. (2011). Modding the global classroom? Serious video games and teacher reflection. Contemporary Issues in Technology and Teacher Education, 11(1), 70-91.

Ghina, A. (2014). Effectiveness of Entrepreneurship Education in Higher Education Institutions. Procedia Social and Behavioral Sciences, 115, pp. 332-345.

Harkema, S., \& Popescu, F. (2015). Entrepreneurship education for adults: a case-study. Procedia - Social and Behavioral Sciences, 209, pp. 213-230.

Hashim, N., Raza, S., \& Minai, M. (2018). Relationship between Entrepreneurial Competencies and Small Firm Performance: Are Dynamic Capabilities the Missing Link? Academy of Strategic Management Journal, $17(2)$, pp. 1-8.

Jin, L., Madison, K., Kraiczy, N., Kellermanns, F., Crook, T., \& Xi, J. (2017). Entrepreneurial Team Composition Characteristics and New Venture Performance: A Meta-Analysis. Entrepreneurship Theory and Practice, 41(5), pp. 743-771.

Katiliütè, E., Daunoriené, A., \& Katkuté, J. (2014). Communicating the Sustainability Issues in Higher Education Institutions World Wide Webs. Procedia - Social and Behavioral Sciences, 156, pp. 106-110.

Keller, G. (2008). Higher Education and the New Society. Baltimore, Maryland: Johns Hopkins University Press.

Komarkova, I., Gagliardi, D., Conrads, J., \& Collado, A. (2015). Entrepreneurship Competence: An Overview of Existing Concepts, Policies and Initiatives. JRC Science and Policy Report. Retrieved from http://publications.jrc.ec.europa.eu/repository/bitstream/JRC96531/jrc96531_final.pdf

Krueger, R., \& Casey, M. (2014). Focus Groups: A Practical Guide for Applied Research. Thousand Oaks, California: SAGE Publications.

La Guardia, D., Genitle, M., Dal Grande, V., Ottaviano, S., \& Allegra, M. (2014). A Game based Learning Model for Entrepreneurship Education. Procedia - Social and Behavioral Sciences, 141, pp. 195-199.

Lamrani R., Abdelwahed E.H., Chraibi S., Qassimi S., Hafidi M., El Amrani A. (2017) Serious Game to Enhance and Promote Youth Entrepreneurship. In: Rocha Á., Serrhini M., Felgueiras C. (eds) Europe and MENA Cooperation Advances in Information and Communication Technologies. Advances in Intelligent Systems and Computing, vol 520. Springer, Cham.

Lan, J., Wong, C, Jiang, C., \& Mao, Y. (2017). The effect of leadership on work-related flow: a moderated mediation model. Leadership \& Organization Development Journal, 38(2), pp. 210-228. 
Liguori, K., Eckman, M., \& Mehta, K. (2014). Reflections on Multidisciplinary Teamwork: From Experience to Impact. International Journal for Service Learning in Engineering, Fall 2014, pp. 283-299.

Lizote, S., Verdinelli, M., Nascimento, S., \& Bervian, L. (2018). Entrepreneurial Competencies and Performance of Undergraduate Programs: A Study of Its Relations Based on Center Directors' Perspective. Journal of Education and Research in Accounting, 12(2), pp. 197-209.

Loi, M., \& Di Guardo, M. (2015). The third mission of universities: An investigation of the espoused values. Science and Public Policy, 42(6), pp. 855-870.

Marer, P., Buzady, Z., \& Vecsey, Z. (2015). Missing Link Discovered - Integrating Csikszentmihalyi's Flow Theory into Management and Leadership Practice by using FLIGBY - the official Flow-Leadership Game. Los Angeles, CA: Aleas Simulations.

Mitchelmore, S., \& Rowley, J. (2010). Entrepreneurial competencies: a literature review and development agenda. International Journal of Entrepreneurial Behavior \& Research, 16(2), pp. 92-111.

Moore, P. (2004). The nature of IT is the antithesis of Business Oriented Thinking. Retrieved from https://it.toolbox.com/blogs/paulamoore/the-nature-of-it-is-the-antithesis-of-business-orientedthinking-033104

Newbery, R., Lean, J., \& Moizer, J. (2016). Evaluating the impact of serious games: the effect of gaming on entrepreneurial intent. Information Technology \& People, 29(4), pp. 733-749.

Protopsaltis, A., Hetzner, S., Borotis, S., Connolly, T., \& Hainey, T. (2014). How to Teach Entrepreneurship Using Serious Games and Web 2.0. In Proceedings of the IEEE 14th International Conference on Advanced Learning Technologies, Athens, Greece, pp. 227-229.

Queirós, A., Faria, D., \& Almeida, F. (2017). Strengths and Limitations of Qualitative and Quantitative Research Methods. European Journal of Education Studies, 3(9), 369-387.

Raju, P., \& Sankar, C. (2014). Serious Games to Improve Student Learning in Engineering Classes. Computers in Education Journal, 5(2), 68-78.

Ramaley, J. (2014). The Changing Role of Higher Education: Learning to Deal with Wicked Problems. Journal of Higher Education Outreach and Engagement, 18(3), pp. 7-21.

Robles, L., \& Zárraga-Rodriguez, M. (2015). Key Competencies for Entrepreneurship. Procedia Economics and Finance, 23, pp. 828-832.

Routledge, H. (2016). Why Games Are Good For Business: How to Leverage the Power of Serious Games, Gamification and Simulations. Basingstoke, UK: Palgrave Macmillan.

Sahoo, F., \& Sahu, R. (2009). The Role of Flow Experience in Human Happiness. Journal of the Indian Academy of Applied Psychology, 35, pp. 40-47.

Sánchez, J. (2012). The influence of entrepreneurial competencies on small firm performance. Revista Latinoamericana de Psicologia, 44(2), pp. 165-177.

Smith, G., \& Shankar, A., (2015). Empowered entrepreneur training handbook. The Global Alliance for Clean Cookstoves. Retrieved from http://cleancookstoves.org/binary-data/RESOURCE/file/000/000/3421.pdf

Sugars, B. (2014). 12 Essential characteristics of an entrepreneur. Retrieved from https://www.business.com/images/content/58a/d9f1f2f87b1207f720c3d/0-0-/

Van der Hoeff, K. (2013). Success of Entrepreneurial Teams. BSc. thesis in Finance and Organization, University of Amsterdam (UvA). Retrieved from file://C:/Users/ferny/Downloads/2013_bachelor_thesis_karlijn.pdf

Yoon, H. (2018). Exploring the Role of Entrepreneurial Team Characteristics on Entrepreneurial Orientation. SAGE Open, 8(2), pp. 1-14.

Zarefard, M., \& Cho, S. (2017). Relationship Between Entrepreneurs Managerial Competencies and Innovative Start-Up Intentions in University Students: An Iranian Case. International Journal of Entrepreneurship, 21(3), pp. 1-12.

Zumeta, L., Basabe, N., Wlodarczyk, A., Bobowik, M., \& Páez, D. (2016). Shared flow and positive collective gatherings. Anales de Psicologia, 32(3), pp. 717-727. 